\title{
Työelämän tutkimus vaatii monitieteistä tutkimusotetta
}

\author{
ANNIKKI JÄRVINEN
}

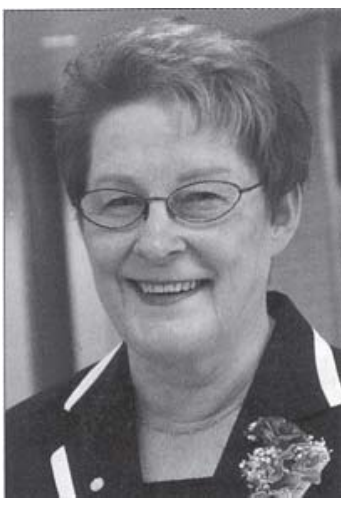

Kuluneena syksynä tuli kuluneeksi 60 vuotta siitä, kun Urpo Harva nimitettiin maamme ensimmäiseksi kansansivistysopin professoriksi. Eurooppalaisittain Suomi oli edelläkävijä. Sittemmin Yhteiskunnallisesta korkeakoulusta tuli Tampereen yliopisto ja kansansivistysoppi muuttui aikuiskasvatustieteeksi. Tuon viran haltijana oli sittemmin myös Annikki Järvinen 1997-2005. Hän oli samalla ensimmäinen aikuiskasvatuksen professoriksi nimitetty nainen Suomes$\mathrm{sa}^{1}$. Virka sai kuitenkin alamääritteeksi ammatillisen aikuiskoulutuksen. Julkaisemme professori emerita Järvisen muistumia sekä hänen "tiedepoliittisen testamenttinsa". Teksti perustuu hänen jäähyväispuheeseensa Tampereen yliopistossa.

Hakeuduin Tampereen yliopiston vastavalmistuneena psykologina syksyllä 1967 Yhteiskuntatieteelliseen Tutkimuslaitokseen, minne oli perustettu maan ensimmäinen korkeakoulupedagogiikan tutkimusassistentuuri. Legendaarinen rehtori Paavo Koli kutsui jo muutaman työviikon jälkeen nuoren tutkimusassistentin puheilleen, ja kertoi näkemyksenään, että tulevaisuudessa yksi tärkeimpiä opiskelumuotoja on ryhmässä opiskelu ja ongelmien ratkaiseminen ryhmätyönä, ja näitä asioita on syytä tutkia. Hän oli myös tässäasiassa aikaansa edellä.

Elettiin hallinnonuudistuksen kiivaita alkuaikoja, ja siinä mylläkässä huomasin yht'äkkiä olevani ns. demokraattisesti valitun laitosneuvoston puheenjohtaja, ja tätä ilosanomaa piti käydä jakamassa myös muissa yliopistoissa. Samoihin aikoihin nousi toinen merkittävä uudistusaalto korkeakoulupolitiikassa eli eri alojen tutkinnonuudistus käynnistyi 1970-luvun alussa. Innostuin kasvatustieteilijänä mielekkäistä ja kiinnostavista uudistustavoitteista ja halusin mukaan tutkijan kammiosta uudistuksen toteutuksen kehittelyyn.

Alkuvaiheessa tutkinnonuudistuksen tavoitteiksi kirjattiin opintojen tehokkuuden, joustavuuden ja mielekkyyden periaatteet, luovuuden ja kriittisen ajattelun tukeminen sekä yhteiskunnalliset tavoitteet, kuten ammatillisen tehtävä- järjestelmän muutoksen huomioiminen, yliopiston ja ympäristön välimatkan supistaminen sekä tutkintojen vertailtavuus ulkomaisiin tutkintoihin. Tehokkuutta pidettiin kuitenkin muiden tavoitteiden saavuttamisen välineenä. Pedagogisten työskentelytapojen pohdinta oli vilkasta ja tutkimuslähtöistä. Joustavuustavoitteen saavuttamiseksi tuli:

- lisätä opiskelijan valinnanmahdollisuuksia nykyisestä,

- voida sisällyttää samaan tutkintoon tasaveroisina erityyppisiä sisältöjä tekemättä eroa tietojen hankkimisen ja taitojen harjoittamisenkesken,

- voida sisällyttää tutkintoon eri alojen opiskelua paremmin kuin nykyisin,

- ulottaa opinnot yli tiedekunta- ja korkeakoulurajojen nykyistä paremmin,

- suosia erilaisia opiskelumuotoja siten, että toisaalta itsenäinen työskentely, toisaalta ryhmätyönä tapahtuva ongelmanratkaisu ja ns. projektityöskentely voivat muodostaa tasave roisen osan opintosuorituksista traditionaalis ten muotojen rinnalla.

Kuulostavat melko tutuilta? Ne on kirjattu kuitenkin tutkinnonuudistuksen tavoitteiksi 35 vuotta sitten! 1960-luvun lopun ja 1970-luvun alun kiihkeässä korkeakoulupoliittisessa ilmapii- 
rissä myös tutkinnonuudistus politisoitiin nopeasti. Kun idealistisena korkeakouluopiskelun tutkijana hakeuduin juuri perustettuun Tampereen yliopiston lääketieteelliseen tiedekuntaan suunnittelijaksi, koska siellä oli kehitteillä uuteen lääkäritutkintoon innovatiivisia korkeakoulupedagogisia opiskelumuotoja, en todellakaan aavistanut, mihin pääni pistin. Varsin pian kävi selväksi, että tutkijalle turvallista puolueetonta maaperää ei ollut. Oli oltava jonkun puolesta jotakuta vastaan, halusit tai et. Professori Jarmo Visakorpi toimi lääketieteen alan valtakunnallisen tutkinnonuudistustoimikunnan puheenjohtajana ja minä suunnittelijana. Uudistusmielisenä yksikkönä Tampereen lääketieteellinen tiedekunta leimautui varsin pian Opetusministeriön käsikassaraksi, ja uudistusten hyvätkin pedagogiset perustelut leimattiin DDR:stä kopioiduiksi ratkaisuiksi, joiden tarkoituksena oli salakuljettaa tämän Troijan puuhevosen avulla sosialismi Suomeen.

\section{Jotakin jäi itämään...}

Myrskyssä ja ristipaineissa tiedekunta kuitenkin kehitteli varsin modernin integroidun opetussuunnitelman, mikä oli nykyisen ongelmaperustaisen opetussuunnitelman esiäiti tai -isä. Valtakunnallinen tutkinnonuudistusaalto vaimeni vasta 1980-luvulla, ja lääketieteellisenkin tiedekunnan uudistusten kehittelijät joutuivat sen tosiasian eteen, että opettajavirkojen uudet tulokkaat toivat mukanaan traditionaaliset ratkaisut, ja integroitu opetus purettiin suureksi osaksi.

Jotakin jäi itämään, josta sitten ongelmaperustainen opetus lähti nousuun 1990-luvulla.

Nyt menossa oleva Bolognan prosessin käynnistämä tutkinnonuudistus tuntuu tuon edellisen uudistusaallon veteraanista varsin aneemiselta ja byrokratiaveroiselta. Nyt eivät nuoret kolmekymppiset opettajat, opiskelijat sekä virkanaiset ja -miehet väittele kiihkeästi aamutunneille asti seminaareissa mm. yleisopintojen tiedepoliittisesta luonteesta ja syventävien opintojen kriittistä ajattelua tukevista toteutusmuodoista tai polta tutkinnonuudistusmietintöjä roviolla, kuten Jyväskylän torilla tapahtui.

1970-luvun lopulla minua alkoi kiinnostaa pitkäjänteinen seurantatutkimus aiheena lääketieteen opiskelijoiden tiede- ja ammattikäsitykset. Tutkimus koski kaikkia lääketieteellisiä tiedekuntia kuuden vuoden ajan. Tein tutkimustyötä vaivihkaa suunnittelija toimen ohessa, enkä suunnitellut tietoisesti väitöskirjaa. Kun lopputulema kuitenkin oli mielestäni varsin kiinnostava, vein valmiin käsikirjoituksen professori Reijo Raivolalle arvioitavaksi. Väitöskirjahan siitä tuli, ja sen myötä siirryin viideksi vuodeksi opetustyön pariin lääketieteellisessä tiedekunnassa käynnistyneen terveydenhuollon opettajankoulutuksen lehtoriksi.

Tutkimusteemaksi nousi reflektiivinen ammattikäytäntö, erityisesti lääkärin ja silloin myös opettajan työssä. Aihe oli varsin uusi Suomessa ja kansainvälisestikin vähän tutkittu. Se sijoittui koulutuksen ja työelämän välimaastoon ja oli luonteva siirtymä kohti työelämätutkimuksen orientaatiota. Korkeakoulututkimus tuli vielä uudelleen tutuksi, kun toimin muutaman vuoden Jyväskylässä Kasvatusalan tutkimuslaitoksen eli KTL:n korkeakoulututkimuksen osastonjohtajana. Siellä oli menossa mm. erään jälleen uuden uudistushankkeen seurantatutkimus. Kyseessä oli ns. työvelvollisuuskokeilu, jonka koekaniineina olivat $\mathrm{mm}$. Jyväskylän yliopiston opettajat ja tutkijat. Tämä hanke toteutettiin sittemmin työsuunnitelmien muodossa kaikissa korkeakouluissa, ja sen kiisteltyjä hedelmiä nautimme edelleen.

\section{Organisaation, työn ja asiantuntijuu- den kehittyminen}

Tampereelle palatessani vuonna1991 oli menossa tutkimus, joka ennakoi tulevien vuosieni suuntaa: aikuisopiskelijan orientaatiot työn ja koulutuksen maastossa. Tutkimus linkittyi pian vuonna 1995 käynnistyneeseen yhteistyöhön kolmen muun aikuiskasvatuksen tutkijan sekä työelämän tutkijan kanssa. Meitä yhdistävä keskeinen intressi oli, miten löytää välittävä tutkimusote yksilön ja kontekstin välisen vuorovaikutuksen tutkimiseen, ja siinä erityisesti kehittymisen ja oppimisen kaltaisten ilmiöiden tutkimiseen. Elinikäisen oppimisen paradigman operationalisoiminen työorganisaatiossa työssä tapahtuvaksi ja yksilöllistä kasvua tukevaksi oppimiseksi koetettiin haastavaksi tehtäväksi.

Tutkimusryhmä tuotti käsitesuhdemallin, jossa tarkasteltiin erityisesti organisaation kehittämisen, asiantuntijuuden kehittymisen ja työn käsitteellistymisen leikkauspintoja. Tutkimushanke, jonka nimenä oli Työ ja koulutus muutoksessa - vaikuttavan oppimisen organisoiminen, sai 
Suomen Akatemian rahoituksen ja pääsi mukaan Koulutuksen vaikuttavuus -tutkimusohjelmaan.

Tänä aikana syntyivät Hannu Valkaman, Esa Poikelan ja Tapio Koiviston väitöskirjat. Tutkimushankkeen lopputeesejä olivat mm. 1) Oppimisen tarkastelu organisaation tasolla ei riitä, vaan tarkastelu on ulotettava laajempaan kontekstiin, 2) koulutuspolitiikkaa ja oppimisen organisoimista ei tule ohjata koulutuksen tuloksellisuus-käsitteen, vaan vaikuttavuuden käsitteen avulla, 3) työssä oppimisen, ammatillisen kehittymisen ja organisationaalisen tiedonmuodostuksen prosessien yhdentäminen tuottaa ydinosaamista, ja 4) oppimisen organisoiminen vaikuttavasti ja tuloksellisesti edellyttää yksilöiden ja työyhteisöjen osallistumista muutoksen suunnitteluun.

Tuloksista henkii toisaalta vahva kritiikki yleiseen työelämän ja organisaatioiden kehittämisjargoniin ja toisaalta vahva konstruktivistisen tutkimuksen leima, josta hyvänä esimerkkinä Tapio Koiviston jalostaman osallistavan uudelleensuunnittelun hyödyntäminen lukuisilla työpaikoilla.

\section{Naisenergiaa}

Tämän Akatemia-hankkeen rinnalla oli toinen hyvin mielenkiintoinen tutkijaryhmä, joka myös pyrki koulutuksen vaikuttavuuden tutkimusohjelmaan, mutta hakemus joutui hakoteille toimistovirkailijan virheellisen merkinnän vuoksi. Virhettä ei suostuttu korjaamaan, ja niinpä sitten viisi hoitoalan ammattilaista alkoi rivakasti työstää väitöskirjojaan vaativan leipätyön ohessa. He saivat koko aikana vain muutaman kuukauden satunnaista stipenditukea. Toimin terveydenhuollon koulutuksen dosenttina heidän ohjaajanaan ja sain todella kokea, mitä naisenergia ja -synergia parhaimmillaan saa aikaan!

Tämä Akatemian reputettujen näyttely tuotti kuudessa vuodessa viisi väitöskirjaa, mikä lienee tutkijakoulusarjassakin melkoinen ennätys. Yhteenlaskettu saldo toisen hankkeen kanssa oli kahdeksan väitöskirjaa Vaikuttavuus-tutkimusohjelman pää-ja oheistuotoksena. Enpä ole kysynyt, mikä koko ohjelman vaikuttavuus tutkijakoulutuksessa kaikkiaan mahtoi olla?

Terveydenhuollon koulutuksen tutkimusryhmän tulokset liikkuivat vahvasti alan työelämän ja koulutuksen leikkauspinnassa. Ne koskivat hoitotyön opiskelijoiden arvo- ja arvostuskäsi- tyksiä, käsityksiä hoitotyön tiedon luonteesta, ajattelun taitoa ja kriittisen ajattelun kehittymistä.

\section{Työssä oppimisen musta aukko?}

Työ ja koulutus muutoksessa -tutkimusryhmän työskentelyn loppuvaiheessa alkoi kiinnostaa työssä oppimisen "musta laatikko". Halusimme tarkastella yksilön, ryhmän ja organisaation oppimisen kietoutumista toisiinsa ja lisäksi nostaa niiden väliset prosessit esiin. Tuloksena oli työssä oppimisen kokemuksellinen prosessimalli, jota on menestyksellisesti sovellettu niin tutkimuksessa, työorganisaatioiden kehittämistyössä kuin designtyössäkin.

Sekä prosessimallin testaamista tutkimuksessa että työssä oppimisen ilmiön syvällisempää tarkastelua lähdettiin toteuttamaan tutkimushankkeessa Työssä ja työyhteisössä oppiminen, johon saatiin Suomen Akatemian rahoitus vuosina 2001-2002. Hankkeen jatkosuunnitelma sai Akatemian rahoituksen vuosille 2004-2005. Rahoituksen turvin palkattiin neljä tutkijaa, jotka kukin ovat valmistelleet väitöskirjaansa hankkeen parissa. Tälle ajanjaksolle on leimallista myös kansainvälisten suhteiden laajeneminen, ja niiden loppuhuipentumana voidaan pitää Työn ja oppimisen tutkimuksen kansainvälisen konferenssin saamista Suomeen vuonna 2003. Sitä oli pohjustanut onnistunut kokemuksellisen oppimisen konferenssi Tampereella vuonna 1998.

Rehtori Jorma Sipilä asetti joulukuussa 2001 valmisteluryhmän, jonka päätehtävänä oli laatia Tampereen yliopiston työelämän tutkimuksen ja opetuksen kehittämisohjelma ja esitykset ohjelman toimeenpanosta. Toimeksianto liittyi yhteiskuntatieteiden tutkimuslaitoksen uudistamiseen ja sen osana toimivan työelämän tutkimuskeskuksen asemaan ja tulevaisuuteen. Työryhmän jäsenet edustivat varsin laajasti työelämän tutkimuksen alaa Tampereen yliopistossa, siinä olivat jäseninä sosiologian, työpolitiikan, työterveyden, työpsykologian ja -sosiologian, yrityksen taloustieteen ja aikuiskasvatuksen professorit ja työelämän tutkimuskeskuksen kaksi tutkijaa; kaikilla oli meneillään työelämän tutkimukseen liittyviä tutkimushankkeita. Työnsä perustaksi ryhmä kokosi tietoja ja teki selvityksiä alan tilasta Suomessa ja varsinkin Tampereen yliopistossa. Työryhmä jätti loppuraporttinsa rehtorille kesäkuussa 2002. 
Loppuraportissa todetaan, että työelämän tutkimus kattaa mikrotasolla yksilön suhteen työhön, työprosessien sekä työelämän rakenteiden ja sosiaalisten järjestelmien tutkimisen ja laajimmalla makrotasolla yhteiskunnan kokonaisuuteen liittyvien ilmiöiden tarkastelun. Tutkimus kattaa kuitenkin monesti useita tasoja ja tarkastelee niiden välisiä suhteita ja vuorovaikutusta. Edelleen raportissa todetaan, että työelämän tutkimusta voidaan pitää yhteiskuntatieteellisenä tai yhteiskuntatieteiden ja muiden tieteenalojen näkökulmia yhdistävänä, mutta sitä ei voi rajata oppiaineiden eikä tiedekuntarajojen mukaan. Usein työelämän tutkimus on aidosti monitieteistä - ei pelkkänä tieteenalojen rinnakkaisuutena, vaan poikkitieteellisenä tai tieteenalarajoja ylittävänä.

Tutkimusta voidaan määrittää myös tutkimuskohteen mukaan, työelämän tutkimuksen tutkimuskohteita ovat esimerkiksi työmarkkinat, työttömyys, työ- ja työvoimapolitiikka, työoikeus, työsuojelu, työolot ja ergonomia, työelämänsuhteet ja työehdot, työelämän sukupuolijärjestelmä, työorganisaatiot ja niiden johtaminen ja kehittäminen, työprosessit, työelämän innovaatiot, työssä oppiminen ja oppimisprosessit, koulutus ja ammatit, työkulttuurit. Muun muassa kaikilla näillä osa-alueilla tehdään työelämän tutkimusta Tampereen yliopistossa.

\section{Työelämän tutkimuksen haasteita}

Työryhmä toteaa aiheellisesti, että monet laajakantoiset yhteiskunnalliset kehityskulut asettavat työelämän tutkimukselle ajankohtaisia haasteita. Näitä ovat ainakin talouden globalisaatio ja siihen liittyvät kansainvälisten suhteiden muutokset ja lisääntyvä, uudentyyppinen kulttuurien kohtaaminen sekä väestön liikkeet valtioiden sisällä ja välillä, tieto- ja kommunikaatioteknologian nopea kehitys, työorganisaatioiden ja työn muotojen uudistuminen, hyvinvointivaltion muutospaineet Euroopan yhdentyessä ja väestön ikääntyessä, arkielämän rakenteiden muutokset ja ekologisen ja sosiaalisen kestävyyden vaatimukset.

Lisäksi voidaan mainita asiantuntijuus- ja monitaitoisuusvaatimusten kasvu ja niihin liittyvä elinikäisen oppimisen vaatimus, samoin työssä jaksaminen ja työn sekä muiden elämänalueiden vaatimusten yhteensovittamisen ongelmat. Tutkimukselta ei odoteta vain ongelmiin reagoimis- ta vaan myös konstruktiivisia ratkaisuja.

Nämä työelämän kysymykset ovat olleet yhä enemmän ohjelmallisten interventioiden kohteena niin kansallisessa kuin ylikansallisessa politiikassa. Suomessa on esimerkiksi viimeisen 15 vuoden aikana käynnistetty ainakin neljä laajaa kansallista ohjelmaa: työelämän kehittämisohjelma, joka on vaikutuksiltaan laajakantoisin, sitten ikäohjelma, tuottavuusohjelma, työssä jaksamisen ohjelma, jne. Interventioiden ja ohjelmien vaikuttavuuden arvioinnista on tullut nopeasti kasvava uusi tutkimusalue.

\section{Tampereella vahvat mahdollisuudet, joita ei pidä hukata}

Tutkimuksen haasteet koskevat yhtä lailla niin perus- kuin soveltavaa tutkimusta. Tutkimuksen tieteellisen merkityksen rinnalle on nostettu myös yhteiskunnallinen merkitys, ns. yliopistojen kolmas tehtävä, johon sisältyy myös alueellisen kehittämisen tavoitteet. Työelämän kehittäminen tuleekin nähdä nykyistä korostetummin kolmantena tehtäväalueena.

Työryhmän mietinnön julkistamista seurasi lausuntokierros, jonka anti oli nuiva: tiedekunnilla ei ollut halua tai kykyä nähdä olemassa olevaa tutkimuspotentiaalia ja työelämän tutkimuksen ilmeisen selvää keskittymistä Tampereen yliopistoon. Työryhmän punnitut ja realistiset kehittämisehdotukset ovat jääneet toistaiseksi odottamaan toimeenpanoa.

Suurehko osa professorikunnastamme on jäämässä eläkkeelle lähivuosina, ja on toivottavaa, ettei lähinäkö ja lähimuisti petä ja lyhytkestoinen politikointi saa viime metrien päätöksissä yliotetta. On syytä vihdoinkin tunnustaa, että Tampereen yliopistolla on vahvat mahdollisuudet maan johtavaksi työelämän tutkimuksen monitieteiseksi tutkimuskeskittymäksi, jonka synergiaedut ovat ilmeiset. Työelämän tutkimusta tehdään 12 Tampereen yliopiston laitoksessa, joiden viranhaltijoista on yli 20 aktiivisia työelämän tutkijoita, väitöskirjoja oli valmisteilla vuonna 2002 oli noin 60.

Senhetkisen selvityksen mukaan SuomenAkatemia oli tukenut vuosina 1999-2003 Tampereen yliopiston työelämän tutkimusta eri laitoksissa noin 9 miljoonalla vanhalla markalla, mikä on alan tutkimuksen rahoituksesta lähes 43 prosenttia koko maassa, vastaavasti Työsuojelurahaston työelämän tutkimuksen rahoituksesta ko. vuosi- 
na 34 prosenttia on myönnetty Tampereen yliopiston hankkeille.

On tunnustettava nykyinen vahva tutkimuspotentiaali ja yliopiston kolmannen tehtävän valtavat haasteet. Tueksi tarvitaan yliopiston johdon rohkeita ratkaisuja, joiden avulla ylitetään tiedekuntien ja laitosten oppiainekohtainen reviirikilpailu. Tampereen yliopistolla on mahdollisuus tukea yhteiskunnallisesti merkittävää ja tieteellisesti vahvaa monitieteistä tutkimusaluetta, jolla on jo varsin vahvat näytöt. Ongelmana on ollut tutkimuksen hajautuminen eri ainelaitoksiin ja työelämän tutkimuskeskukseen ja aidosti monitieteellisen tutkimusintressin puuttuminen.

\section{Työelämän tutkimus vaatii monitehosilmälasit}

Olen ollut professorivuosinani kolmessa eri hankkeessa mukana, joiden kunnianhimoisena tavoitteena on ollut monitieteisen tutkimuksen käynnistäminen työelämäntutkimusta sivuavilla alueilla.

Ensimmäinen koski tiedon luonnetta erilaisissa konteksteissa, kyseessä oli niin kutsuttu KECOprojekti. Sen parissa eräät informaatiotutkimuksen, kunnallistieteiden, hallintotieteen, aikuiskasvatuksen ja tietojenkäsittelyopin tutkijat tekivät perusteellista käsiteanalyysia ja tutkimuskohteen hahmottamista. Hankkeella oli selvästi vahva kansainvälinen tieteellinen kontribuutio, mutta eräs keskeinen ongelma oli monitieteisen tutkimushankkeen johtamisen organisointi.

Toinen vaativa monitieteinen hanke oli Life as Learning -tutkimusohjelman hakuprosessiin liittyvä tutkimus-konsortium, joka oli Työelämän tutkimuskeskuksen ja kasvatustieteiden laitoksen työssä oppimisen tutkijoiden yhteinen ponnistus. Akatemian toimikunta pirstoi konsortiumin monitieteisen kokonaisuuden ja rahoitti vain toisen osapuolen suunnitelmat. Seuraavana vuonna sitten Akatemia myönsi pois pudotetulle osapuolelle rahoituksen varsin korkeiden asiantuntijoiden arviointien perusteella. Tämä esimerkkinä siitä, miten rahoittajatahon hallinnolliset toimenpiteet voivat nitistää monitieteisyyden idean. Kolmas monitieteinen hanke on syntynyt oman tiedekuntamme sisällä, ja sen teemana on oppimisen dynamiikka muutosprosesseissa eli niin kutsuttu Dyletra-hanke.

Kaikkien näiden kolmen hankkeen suunnitte- lukokemuksen pohjalta voin todeta, että ensinnäkin monitieteiseen hankkeeseen tarvitaan aidosti yhteisen tutkimusintressin omaavat tutkijat, jotka jaksavat käydä perusteellisia käsiteanalyyttisia ja metodologisia keskusteluja. Toiseksi mukaan tulevien tutkimusryhmien tulee olla jo kansainvälisesti etabloituneita ja vahvan rahoituspohjan omaavia. Kolmanneksi ryhmien tulee saada alkuponnistuksissaan suunnitteluresursseja ja sekä yliopiston että tiedekunnan johdon tukea. En tiedä yliopiston tutkimusneuvoston suunnitelmia, mutta mielestäni monitieteisten tutkimushankkeiden erityisproblematiikkaan tulisi todella paneutua. On tärkeitä tutkimuksen alueita, joiden tutkimus tulevaisuudessa vaatii juuri monitieteisen tutkimusotteen haltuunottoa. Näihin tutkimusaloihin kuuluu myös työelämän tutkimus, joka ei pysty vaikeita ja kompleksisia kysymyksiä analysoimaan ja ratkomaan perinteisillä yksitieteisillä ja -tehoisilla silmälaseilla.

Näen aikuiskasvatuksen työelämäorientoituneen tutkimuksen kotipesän olevan juuri tällaisessa aidosti monitieteisessä tutkimusyksikössä, eikä niinkään institutionaaliseen koulutukseen sekä lasten ja nuorten kasvatukseen fokusoivassa kasvatustieteiden tiedekunnassa.

Asetelma on kautta vuosikymmenten ollut se, että kasvatustieteilijät ovat pyrkineet omista lähtökohdistaan määrittämään, mitä työelämäorientoitunut aikuiskasvatus on. Tästä hyvänä esimerkkinä on uusin tulokas yrittäjyyskasvatus. Kun toisaalta kriittiset kasvatustieteilijät jyrähtävät, että yrittäjyyskasvatus näyttää osaltaan olevan postmodernin yhteiskunnan keino kontrolloida "uusiirtolaisten", huonosti koulutettujen, pitkäaikaistyöttömien ja pätkätyöläisten armeijoita"; ja toisaalta yrittäjyyskasvattajat maalaavat, että yrittäjyyskasvatuksen tavoitteena on "yksilön omien valmiuksien kehittäminen kohti aloitteellisuutta, vastuullisuutta ja itsenäistä hyvää oman elämänhallintaa", ei voi olla vakuuttunut siitä, että puhutaan samasta ilmiöstä!

Todelliset haastajat sekä vaativat yhteistyökumppanit työelämäorientoituneelle aikuiskasvatuksen tutkimukselle löytyvät kuitenkin organisaatiotutkimuksen ja työn tutkimuksen suunnasta.

Aikuiskasvattajat ovat puolestaan 1990-luvun lopulta alkaen peräänkuuluttaneet organisaatiotutkijoiden ja yhteiskuntatieteilijöiden panosta elinikäistä oppimista ja työssä oppimista koskevaan keskusteluun. Mm. tunnettujen aikuiskas- 
vatuksen tutkijoiden Forresterin, Boudin ja Garrickin näkemys on, että koska työntekijöiden tiedot, taidot ja asenteet nousivat melko lyhyessä ajassa myös valtiollisten politiikkojen huomion kohteeksi, tarvitaan lisää ymmärrystä työn ja työpaikkojen muutoksesta sekä uudenlaista oppimisen käsitteellistämistä.

Osa tutkijoista on ottanut hyvin kriittisen kannan paljon viljeltyihin käsitteisiin kuten tietoyhteiskunta, elinikäinen oppiminen, oppiva organisaatio ja työssä oppiminen. Forrester toteaakin, että vaatimus elinikäisestä oppimisesta tai oppivasta organisaatiosta on aikaisempaa tehokkaampi työntekijöiden yhä tiukemman sitouttamisen, työn intensivoinnin ja kontrollin muoto. Uudelle työpaikalle ei hänen mukaansa ole tyypillistä suinkaan konsensus, yhteishyvä ja luottamus, vaan konfliktit, jännitteet ja epäluottamus, jotka kumpuavat työn ja pääoman perusristiriidasta.

\section{Sitä ei voi ohittaa, sitä ei voi alittaa...}

On selvää, että aikuiskasvattajan, joka aikoo työelämän tutkimuksen kentälle, on tunnistettava kyseiset jännitteet ja ristiriidat, hän ei voi naivin tietämättömänä puuhastella oppivan organisaation laatikossa. Mutta yhtä epäeettistä, kuin kieltäytyä näkemästä näitä ongelmia, on tyytyä etäisen välimatkan päästä tapahtuviin, viileän elitistisiin kannanottoihin. Yhtä ehdottomasti kuin aikoinaan aikuiskasvatuksen ja vapaan sivistystyön puolestapuhujat ottivat vastaan haasteen koko kansan sivistämisestä, on nykyajan aikuiskasvattajan otettava vastaan haaste aikuisen oikeudesta mielekkääseen työhön ja työympäristöön. Sen tehtävän parissa voi näyttää välillä sinisilmäiseltä idealistilta, mutta ei koskaan kyynikolta. Palkkatyö, kotityö tai vapaaehtoistyö hallitsee valtaosaa aikuisväestön elämänkaaresta. Sitä ei voi ohittaa, sitä ei voi alittaa, on siis mentävä lävitse.

Työelämäorientoituneen aikuiskasvatuksen tutkijoiden ja työn tutkijoiden uusin sukupolvi on löytämässä yhteistä käsitteistöä ja yhteistä metodologista pohjaa, ja heidän mahdollisuutensa uudenlaiseen tieteidenväliseen yhteistyöhön ja työelämän ongelmien ratkomiseen ovat tässä suhteessa paremmat kuin edellisten tutkijasukupolvien. Teoreettisesti yhdistäviä lähestymistapoja on tarjonnut toisaalta sosiaalinen oppimisen teoria, ja toisaalta käytäntöyhteisöjen tutki- mus, tiedon luomisen, välittymisen ja siirtämisen problematiikka, työ- ja oppimisprosessien tutkimus sekä työpaikkakulttuurien tutkimus.

Metodologiset lähestymistavat ovat myös monipuolisempia kuin aikaisemmin; tutkittavaa ilmiötä lähestytään ennakkoluulottomasti erilaisin tutkimusottein, jolloin kompleksisesta ilmiöstä syntyy syvällisempi kuva. Myös perusteellinen jalkautuminen tutkimusmaastoon on kiitettävän innokasta.

Tästä hyvänä esimerkkinä on Suomen Akatemian tukema Työssä oppimisen tutkimusryhmä, jossa on mukana on sekä työn tutkijoita että aikuiskasvattajia. He tuovat väitöskirjoissaan oman mielenkiintoisen panoksensa aikuiskasvatuksen työelämäorientoituneeseen tutkimukseen. He nostavat esiin mm. työn ja oppimisen prosessien yhteenkietoutumisen, oppimisen, työympäristön ja valtasuhteiden jännitteisen suhteen, oppimisen tilan hahmottamisen sekä asiantuntijuuden pirstoutuneen työkuvan. Aikuiskasvatuksella on jo vakiintunut ja tunnustettu vastuualueensa työelämän tutkimuksessa, ja nuorella tutkijasukupolvella kyky ja halu työelämän tutkimuksen monitieteiseen hahmottamiseen ja työskentelyyn.

Toivon, että Tampereen yliopiston johdolla on viisautta nähdä yliopiston selkeät näytöt ja mahdollisuudet toimia tulevaisuudessa työelämän monitieteisen tutkimuksen johtavana yksikkönä maassamme sekä rohkeutta tehdä tiedekunta-ja oppiainereviirejä ylittäviä ratkaisuja tällä sektorilla. Siihen liittyy myös alueellisen osaamiskeskuskonseptin uudelleen tarkastelu siltä osin, että mukaan on liitettävä myös sosiaalisten innovaatioiden tutkimuksen hyödyntäminen työelämän organisaatioiden kehittämistyössä.

\section{Viite}

1. Maija-Liisa Rauste-von Wright hoiti virkaa 11 kuukauden ajan ennen Annikki Järvistä, mutta Järvinen oli ensimmäinen aikuiskasvatuksen professorin virkaan nimitetty nainen. 